\title{
Task 2.8 - Mercury Speciation and Capture in Serubber Solutions
}

\author{
Semi-Annual Report \\ July 1 - December 31, 1996 \\ RECEIVEO \\ Alli 14997 \\ OST \\ By \\ Sumitra R. Ness
}

Work Performed Under Contract No.: DE-FC21-93MC30097

For

U.S. Department of Energy

Office of Fossil Energy

Morgantown Energy Technology Center

P.O. Box 880

Morgantown, West Virginia 26507-0880

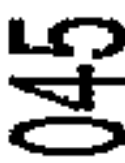

By

Energy and Environmental Research Center

University of North Dakota

P. O. Box 9018

Grand Forks, North Dakota 58202-9018

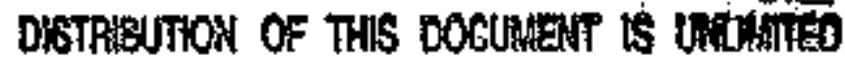

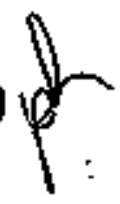




\section{DISCLAIMER}

Portions of this document may be illegible in electronic image products. Images are produced from the best available original document. 


\section{DISCLAMMER}

This report was prepared as an account of work sponsored by an agency of the United States Government. Neither the United States Government, nor any agency thereof, nor any of their employees makes any warranty, express or implied, or assumes any legal liability or responsibility for the accuracy, completeness, or usefulness of any information, apparatus, product, or process disclosed or represents that its use would not infringe privately owned rights. Reference berein to any specific commercial product, process, or service by trade name, trademark, manufacturer, or otherwise does not necessarily constitute or imply its endorsement, recommendation, or favoring by the United States Government or any agency thereof. The views and opinions of authors expressed herein do not necessarily state or reflect those of the United States Government or any agency thereot.

\section{ACKNOWLEDGMENT}

This semiannual was prepared with the support of the U.S. Department of Energy (DOE) Federal Energy Technology Center, Cooperative Agreement No. DE-FC21-93MC30097. However, any opinions, findings, conclusions, or recommendations expressed herein are those of the author(s) and do not necessarily reflect the views of the DOE.

\section{EERC DISCLAIMER}

LEGAL NOTICE This research report was prepared by the Energy \& Environmental Research Center (EERC), an agency of the University of Notth Dakota, as an account of work sponsored by U.S. Department of Energy. Because of the research nature of the work performed, neither the EERC nor any of its employees makes any warranty, express or implied, or assumes any legal liability or responsibility for the accuracy, completeness, or usefulness of any information, apparatus, product, or process disclosed, or represents that its use would not infringe privately owned rights. Reference herein to any specific commercial product, process, or service by trade name, trademark, manufacturer, or otherwise does not necessarily constitute or imply its endorsement or recommendation by the EERC. 


\section{TABLE OF CONTENTS}

LIST OF TABLES $\ldots \ldots \ldots \ldots \ldots \ldots \ldots \ldots \ldots \ldots \ldots \ldots \ldots \ldots \ldots \ldots \ldots$

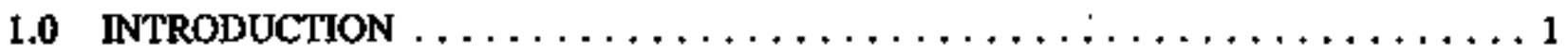

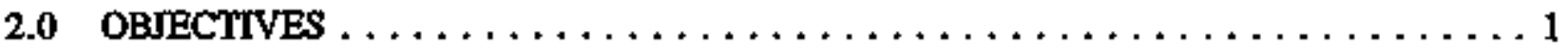

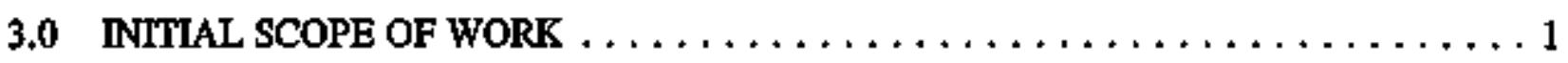

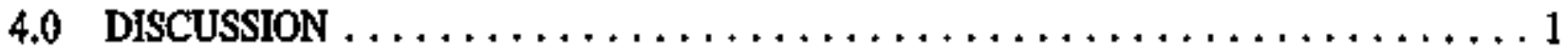

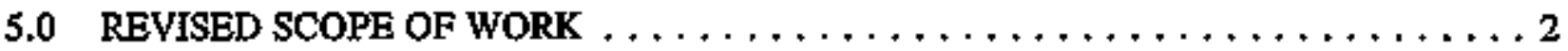

\section{LIST OF TABIES}

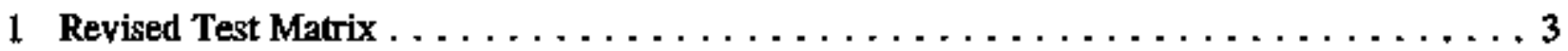




\section{TASK 2.8 - MERCURY SPECIATION AND CAPTURE IN SCRUBBER SOLUTIONS}

\subsection{INTRODUCTION}

Investigations into mercury control across conventional scrubber systems have precipitated questions concerning 1) the initial speciation between oxidized and elemental forms of mercury in flue gas from coal-fired boilers and, subsequently, 2) the effects of scrubber slurry composition and $\mathrm{pH}$ on the mercury forms. Mercury capture in scrubber slurry is highly dependent on its form. Oxidized mercury is highly water-soluble and can be removed by scrubber shurry, whereas elemental mercury is not and passes through the scrubber to the stack.

\section{2,0 ORJECTIVES}

The objectives of this project are to determine whether scrubber solutions convert either form of mercury to another and whether mercury capture is affected by $\mathrm{pH}$.

\subsection{INITIAL SCOPE OF WORK}

The mercury bench-scale test anit in the Energy \& Environmental Research Center (EERC) Particulate Research Laboratory will be used to perform these tests. A bench-scale scrubber will be consinucted to achieve the desired liquid-to-gas ratios and/or sulfur dioxide and mercury removals. Major variables include high and low pH and two of three shurry compositions (lime-based, limestone-based, and scrubber solution from a local utility). Simulated flue gas $\left(\mathrm{SO}_{2}, \mathrm{NO}_{\pi}, \mathrm{CO}_{2}\right.$, $\mathrm{H}_{2} \mathrm{O}, \mathrm{O}_{2}$, and balance $\mathrm{N}_{2}$ ) spiked with either or both elemental and oxidized mercury from commercially manufactured calibration tubes will be scrubbed while inlet and outlet elemental mercury concentrations will be meastured using the on-line contimuous emissions monitor, SemTech.

\subsection{DISCUSSION}

- Simulated scrubber slurry components and scrubber siurry from a local utility as well as laboratory equipment required for the project have been procured.

- Quantities and flow rates of the gases and mercury spiking have been determined.

- The bench-scale unit has been set up and should be operational through the month of February 1997. Modifications to the $\mathrm{pH}$ maintenance system and extra heating/insulation are still required.

Bench-scale tests, which were to proceed in August 1996, were put on hold because of downtime on the SemTech mercury analyzers and conversion systems which were serviced on- site over Thanksgiving 1996. The SemTech analyzers have since been in full use for other delayed 
projects. This joject will now have full use of a SemTech analyzer for the month of February 1997. Use of the on-lime analyzer, such as the SemTech, for both elemental and oxidized mercury was initially preferred because real-time changes in mercury capture could be recorded as the scrubber solution was spent. The main advantages of using the SenTech were the ability to shake down operation of the unit and investigate more variables for the same cost and in a shotter amount of time than with wet chemistry methods which are time-averaged over 30-60 minutes and expensive; the project budget would only support eight analyses. Other disadvantages of the wet chemistry methods were the continuing disptte over which metwods (or whether any of the methods) adequately capture oxidized forms of mercury. Therefore, it was determined that the project should be posponed until issues with the SemTech could be adequately addressed. When the scope of work for this project was initially proposed, it was believed that the wet chemistry methods would be validated and the on-line analyzers/conversion systems both would be successfully operational by the project start date. At this time, a revised scope of work is proposed and will be completed by March 31, 1997. A discussion of the Particulate Research Lab's capabilities for mercury spiking, bench-scale studies, and the SemTech follows.

The SemTech analyzer only measures eiemental mercury and uses a converston system to convert oxidized forms of mercury to elemental mercury. The oxidized fraction is measured by difference between the total mercury in converted samples less the mercury in unconverted samples. At this time, the SemTech analyzer and its conversion system appear to be working within the range of instrument specifications. However, the bench-scale mercuric chloride spiking system has not yet yielded reproducible results before and after a systern shutdown but does yield reproducible results within a given day. It has not yet been determined if the data discrepancies are because of the mercuric chloride spiking system, the SemTech conversion system, the SemTech analyzer, or the wet chemistry methods used as backup data for the mercuric chloride spiking system calibrations.

In contrast, the elemental mercury spiking system and SemTech analyzer results have been favorable. Since elemental mercury is predicted to pass through the scrubber solutions unaffected as has been shown at the full scale, the focus is on the behavior of oxidized mercury in the scrubber solutions. However, there is some evidence at the full scale that oxidized mercury is converted into elemental mercury across wet scrubbers. This effect is small (s10\%) and, as of yet, not confirmed. Therefore, both elemental mercury and mercuric chloride will not be spiked in combination because of the possibility of this effect.

Based on the capabilities of the SemTech analyzer and currently favored wet chemistry methods, a revised scope of work has been determired.

\subsection{REVISED SCOPE OF WORK}

Results which have been determined by the many mercury projects at the EERC and other research facilities that affect the scope of work for this project are as follows:

- Results from wet chemistry methods are affected by the presence of, but not quantities of (as found in typical combustion flue gas), $\mathrm{HCl}$ and $\mathrm{NO}_{\mathrm{x}}$ and will be a constant, not variable, component of the simulated flue gas. 
- The tris-buffer method, not EPA Method 29, is currently favored for the most accurate mercury speciation results.

- Mercuric chloride mass balances cannot be obtained unless all surfaces line surfaces are heated to at least $250^{\circ} \mathrm{F}$. Since the scrubber carnot be operated at this temperature, several modifications are required to heat all of the scribber surfaces and components to at least $150^{\circ} \mathbf{F}$. However, deposition of mercuric chloride is still likely and may be a major obstacle to obtaining definitive data from this study. A revised $2^{3}$ test matrix has been developed where

$$
\begin{gathered}
\text { pH: }-=\text { low pH and }+=\text { high pH } \\
\text { Slurry:- }=\text { Lab Shurry and }+=\text { Commercial Shurry } \\
\text { Hg Species:- }=\mathrm{Hg}^{0} \text { and }+=\mathrm{Hg}^{+}
\end{gathered}
$$

TABLE 1

Revised Test Matrix

\begin{tabular}{lccc}
\hline Run & pH & Slurry & Hg Species \\
\hline 1 & - & - & - \\
2 & + & - & - \\
3 & - & + & - \\
4 & + & + & - \\
5 & - & - & + \\
6 & + & - & + \\
7 & - & + & + \\
8 & + & + & + \\
\hline
\end{tabular}

The initial scope of work intended to use two sluries: one lime and one limestone. Since commercial scrubber slurry inclutes many oxidizing and chlorine-containing additives (for disinfection, etc.), it is preferable to use it in lab characterization. The revised scope of work shows one lab and one commercial slurry. If the data warrant and enough time remains in the project, a second lab slurry will be tested.

The objectives for the revised scope of work are as follows:

- To detemine if an effect in scrubber slurry removal of mercury is dependent upon pH for both elemental mercury and mercuric chloride. 
- To determine if under the same conditions laboratory-prepared sherries show the same results as commercial slurries which contain antibacterial agents and other oxidizers.

- To determine if a detectable amount of mercuric chloride is converted to elemental mercury in the scrubber solution.

All measurements for tests (and corresponding blanks) spiked with elemental mercury will be made with the SemTech analyzer. All measurements for tests (and corresponding blanks) spiked with mercuric chloride will be made using the tris-buffer mercury speciation method. The error of the SemTech analyzer and conversion system is not great enough to conclusively detect a $10 \%$ conversion of mercuric chloride to elemental mercury, whereas the error of the tris-buffer method is approximately equal to $10 \%$. Therefore, it is possible that the tris-buffer method may be able to show the presence of, but not quantitate, the conversion. Sulfur dioxide will be regulated at the inlet with mass flow controllers and checked at the outlet using a portable electrochem analyzer. The $\mathrm{pH}$ of the slurry will be monitored with a $\mathrm{pH}$ meter as well as litmus paper. Temperatures will be monitored throughout the system. All data will be recorded manually. The final report for this project will be written in March 1997. 


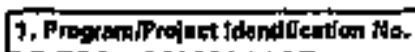
DE-FC21-9340\$0097

4. Name and Address
2. Progromifrotiot TIU0 TASK 2.0 ALR OUAUTY ASSESSMENT AND CONTEOL

Energy \& Environmertal Research Center University of North Dakota

PO Box 9018, Grand Forks, ND 59202-9018
(701) $777-5000$
3, Raportiag Partiod

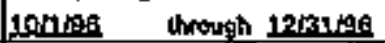

5. Progran Start butw 1-12.93

6. Complesion Dato $.12 \cdot 31 \cdot 97$

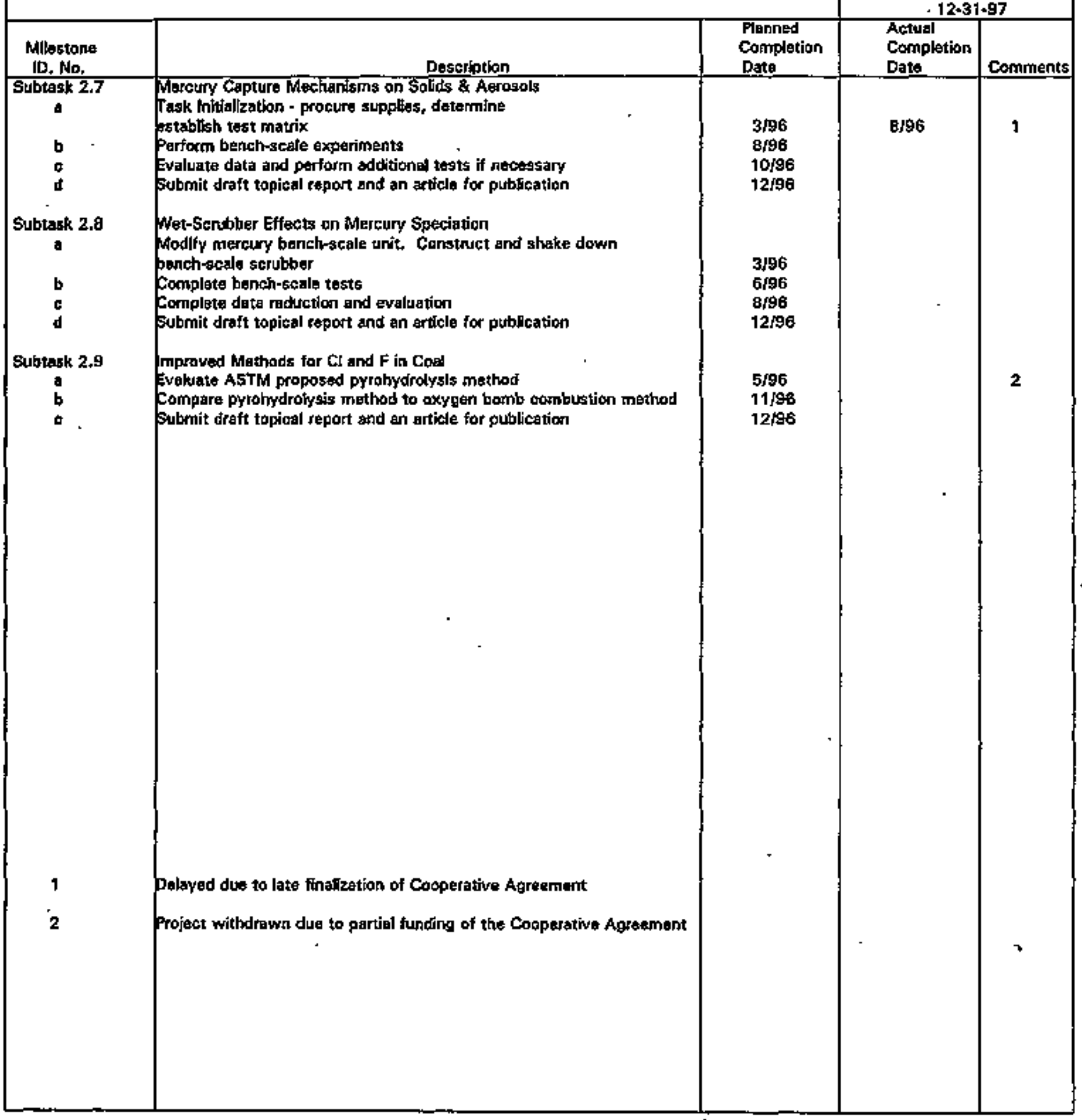

